\title{
Gender differences in visitor motivation and satisfaction: the case of Golija-Studen- ica Biosphere Reserve, Serbia
}

\author{
Snežana Milićevićl, Živana Krejić² \& Nataša Đorđević ${ }^{1}$ \\ Keywords: UNESCO Biosphere Reserve, Golija-Studenica Biosphere Reserve, visitor motivation, visitor satisfaction, gender, \\ Serbia
}

\section{Abstract}

The UNESCO Golija-Studenica Biosphere Reserve (BR) is located in southwestern Serbia. Its captivating beauty, breath-taking landscape diversity, and preserved natural and cultural values make it one of the country's most beautiful mountains. This paper aims to determine the differences in motivation and level of satisfaction with the tourism offer of Golija-Studenica BR based on the visitor's gender. Motivation and satisfaction of 642 visitors to Golija-Studenica BR were analysed using factor analysis, Cronbach's alpha coefficient and regression analysis. Research findings confirm that gender matters - there is a gender-based impact on the motivation and satisfaction of visitors. The paper makes both scientific and practical contributions. Thus far, insufficient attention has been given to researching motivation and satisfaction of visitors to biosphere reserves in Serbia. Therefore, this paper can serve as a scientific basis for future research, for the improvement of the tourism offer of GolijaStudenica BR with the aim of encouraging its diversity, and for the development of sustainable tourism in this destination.

\section{Profile}

Protected area

\section{Golija-Studenica}

\section{Biosphere Reserve}

Mountain range

\section{Dinaric Alps}

Country

\section{Serbia}

\section{Introduction}

Biosphere Reserves (BRs) are areas of terrestrial or coastal / marine ecosystems, or a combination of the two (Biosphärenpark Wienerwald Management 2016), internationally recognized under UNESCO's Man and the Biosphere (MAB) Programme. Together, BRs form the World Network of Biosphere Reserves, which includes representative examples of all major natural and semi-natural ecosystems. BRs, by definition and intent, have economic and social benefits for local people, but also have the value of demonstrating sustainable development linked to conservation in the wider biogeographical region (UNESCO 2020a). The MAB Programme is among UNESCO's flagship programmes and is prioritized for linking landscape and nature to sustainable development. The overarching goal of the MAB Programme is the harmonious development of people and their environments (Köck et al. 2009; Ruoss 2013; Braun et al. 2020). The growth of nature-based tourism has raised the need for a better understanding of visitor expectations with regards to outdoor recreation environments (Tyrväinen et al. 2017). People who are aware of the need to protect natural resources are opting in large numbers to visit protected natural areas (Trišić 2019). Natural areas, when protected, not only conserve the natural environment but also function as social spaces, where tourism brings increased income,

\footnotetext{
1 University of Kragujevac, Faculty of Hotel Management and Tourism in Vrnjačka Banja, Vrnjačka Banja, Serbia.

2 Union University-Nikola Tesla, Faculty of Business Studies and Law, Belgrade, Serbia.
}

employment, and financial support for conservation. In this context, visitors' satisfaction with their experiences in the protected areas is an important objective that depends not only on the protected area itself but also on the services provided (Oviedo-García et al. 2019).

Numerous studies have found links between visitor motivation and satisfaction with a destination's offer. Visitors are more likely to choose destinations which they believe will best fulfil their internal needs (Meng et al. 2008). Motivation refers to psychological need and the wish to fulfil desires, and it explains why visitors behave in a certain manner (Beh \& Bruyere 2007; Mehmetoglu \& Normann 2013). To understand visitor motivation is to recognize why a person chooses a certain destination (Sandybayev et al. 2018). Visitor motivation is the combination of needs and desires that affect the propensity to travel in a general sense, which can also differ according to the person's age, gender and nationality (Meng et al. 2008). Wu (2015) states that visitor motivation refers to a person's desires, such as to relieve pressure, to enjoy the natural environment, to experience beautiful scenery and to learn, which drive the individual to go on vacation. On the other hand, visitor satisfaction is defined as an individual's emotional state after experiencing a trip (Baker \& Crompton 2000), i. e. positive feeling or pleasure gained from the experience or from consuming any tourism product. It includes the evaluation of the travel experience or the tourism product in terms of visitor motivation (Buckley 2009; Ma et al. 2018).

Studying the motivation and satisfaction of visitors in an empirical manner has become a primary task for many researchers, especially in protected areas, be- 
cause interaction with nature affects satisfaction with the visitor experience (Mutanga et al. 2017). DiazChristiansen et al. (2016) and Mahika (2011) found that the main motives for visiting natural areas in Ecuador were intellectual, social, challenge and relaxation. Fung and Jim (2015) in their study of nature-based tourism in the Hong Kong Global Geopark identified three main motivation categories relating to natural environment, heritage, social aspects and approachability (of personnel, of local people). Motivation factors such as social aspects, relaxation, escapism, nature and recreation have commonly appeared in studies about naturebased tourism. Carvache-Franco et al. (2020) state that the main motives for visiting the Samanes Protected Area in Ecuador are "to enjoy the environment and pure air", "to enjoy its public recreation spaces", "to do sports" and "to engage in activities in nature", while the most valued attributes in the satisfaction are "personal safety" and "places of recreation". Lee et al. (2014) found that the motives "relax and escape" and "seek knowledge" were significant predictors of repeat visits to ecological parks in South Korea.

Various factors may affect destination choice, for example age, income, personality, cost, distance, risk and motivation (Kozak 2002). Demographic and socio-economic characteristics have mainly been used as the basis of visitor segmentation. However, the power of age, gender and wealth in predicting purchasing behaviour is markedly situation-dependent, because they are only indirectly related to purchasing intentions (Park \& Yoon 2009). A correlation between visitors' sociodemographic characteristics, such as gender, age, education level and income, and their motivation and satisfaction has been reported in some earlier studies (Jang \& Feng 2007; Jönsson \& Devonish 2008). Mutanga et al. (2017) conducted research in two national parks in Zimbabwe and proved the correlations between age and motivation, education level and motivation, income level and motivation, as well as visitor origin and experiences with wildlife. Ma et al. (2018) examined the relationship between sociodemographic, motivational and satisfaction factors for visitors to two protected areas in South China. Kim et al. (2008) suggested that younger people are more motivated by novelty-seeking than older people.

Some studies deal exclusively with differences in visitors' motivation and satisfaction based on their gender. Tourism itself is a product of gendered societies, and its processes are gendered in their construction, presentation and consumption (Pritchard $\&$ Morgan 2000). In the tourism industry, gender has been considered an important determinant of tourist or visitor behaviour and may be of great use in segmenting markets (Um \& Crompton 1992). Women and men are involved differently in tourism consumption (Swain 1995; Figueroa-Domecq et al. 2015). Andreu et al. (2006) consider that female tourists have stronger relaxation and escape-based motives, while male tourists prefer recreation and activity at the desti- nation. Suki (2014) states that male and female visitors may have rather different views of the relationship between service quality dimensions and tourist satisfaction. Thus, ignoring any gender-based differences may create a false picture. Kwok et al. (2016) point out the differences in visitor satisfaction at the destination when it comes to men and women, and state that women choose destinations with a modern and attractive tourism offer because this gives them a higher degree of satisfaction. There are gender differences in visitor perceptions, preferences and attitudes, and this should influence how marketing managers promote tourist destinations (Ryan et al. 1998).

Women tend to spend significantly more money than men. It is therefore important to extend, adapt and modernize the offer to continue the trend of (women's) increasing spending. It is also important to examine what products and services would increase men's willingness to spend more money (Krejić et al. 2016).

Schlagenhauf (2010) points out that more men than women travel for leisure. Gender may influence how sites are interpreted for visitors, as well as the associations that visitors make with places. Women's motivations for travel are often related to childhood memories and family life (Squire 1994). Compared to men, women are motivated by a sense of safety while travelling and staying in a tourism destination, which also brings them a higher level of satisfaction (Rittichainuwat 2008). Chen and Kerstetter (1999), in a study of the image of Pennsylvania as a rural tourism destination, conclude that women were more likely than men to agree that the tourism infrastructure and natural values of the destination are important for the destination's image. Women also have higher destination-related expectations than men (Wang et al. 2016). Furthermore, in developing countries and patriarchal societies, the relations between women and men are quite specific, which influences their travel choices (Brown \& Osman 2017).

This study aims to investigate gender differences concerning the effect of motivation on satisfaction with the tourism offer in Golija-Studenica BR.

The main research questions of the study are:

- What are the motives for visiting Golija-Studenica $\mathrm{BR}$, and what are visitors' levels of satisfaction with the reserve's tourism offer?

- Does the visitor's motivation affect their level of satisfaction with Golija-Studenica BR's tourism offer?

- Are there gender-based differences in visitor motivation on satisfaction with Golija-Studenica BR's tourism offer?

\section{Study area}

Golija-Studenica BR is situated in southwestern Serbia, in the inner zone of the Dinaric mountain system (Dinaric Alps). The mountainous region 
includes a mosaic of different ecosystems such as forests, shrubs and lakes (UNESCO 2020b). Golija Mountain is classified as an area of special natural and cultural values; it is a site where the quality of the landscape and the physical structure of settlements are of outstanding importance for the development of tourism. It is therefore necessary to pay special attention to the protection of the landscape, planning and development (Josimovic \& Crncevic 2012). The mountain has a network of streams that cut through gorge-like valleys. The most picturesque among them are those of the Studenica and Izubra rivers. The mountain is adorned with a vast expanse of forest cover that includes Heldreich's or the Balkan maple (Acer heldreichii), making these the most beautiful (and best-conserved) deciduous and mixed deciduousconiferous forests in Serbia. The mountain is also home to about 1100 plant species, many of which are relict or endemic (e.g. Allysum markgrafi, Allysum jancheni, Pancicia serbica, Viola elegantula, Vferbasaim adamovicii, Thymus adamovcii). In addition to numerous mammalian species, such as the lesser mole-rat (Spalax leucodon), alpine shrew (Sorex alpinus), brown bear (Ursus arctos), wolf (Canis lupus) and fox (Vulpes vulpes), Golija Mountain is inhabited by almost 100 highly significant bird species, including woodlark (Lullula arborea), rock partridge (Alectoris graeca), common redshank (Tringa totanus), and common redstart (Phoenicurus phoenicurus) (Institute for Nature Conservation of Serbia 2020; Dingarac \& Pesic 2011).

Golija-Studenica BR was the first BR to be established in Serbia. It was designated in 2001 on the basis of the natural values of Golija Nature Park and the cultural heritage of the twelfth-century Studenica Monastery, which is inscribed on the UNESCO World Heritage List. Golija-Studenica BR covers over 70\% of the territory of the Golija Nature Park, and has an area of about 54000 ha, where some of the most valuable sites, both natural and cultural, are located. Preserved forest ecosystems flourish throughout the territory of the Nature Park and the Biosphere Reserve (Institute for Nature Conservation of Serbia 2020).

Since ancient times, Golija has attracted visitors who wished to explore it (Krejić et al. 2017). The tourism offer is diverse, and tourism in Golija is currently developing extremely rapidly (Lakićević \& Sagić 2019). Thanks to the preserved state of nature here, the mountain offers numerous opportunities for visitors, the most popular of which are skiing, hiking, mountaineering, paragliding and cycling. Given the extraordinary wealth of its fauna, Golija is very attractive to hunters and fishermen. With 95 bird species, Golija is also one of the most important ornithological mountain sites in Europe. The diversity of the area's birds encourages birdwatching and enriches the tourism offer. Golija also offers visitors unique nature expeditions, in the form of survival programmes and education in nature. One of the most beautiful possibilities for children and adults is a full-day walk through the dense forests while collecting medicinal herbs, picking mushrooms, wild strawberries and blueberries, and encountering wild horses that run free on green pastures (Ivanovski \& Popović 2018; Josimovic \& Crncevic 2012). The existing natural resources should be a significant factor in the current intensive tourism development of mountains generally, and particular emphasis should be placed on the development of ecotourism (Milićević et al. 2020).

The cultural heritage of Golija consists of monuments of exceptional importance dating back to the golden age of the medieval period (Studenica Monastery and Gradac Monastery); various structures and artefacts from prehistory that survive to the present day; preserved natural and rural environment; significant traces of medieval mining, and examples of preserved traditional architecture. A number of cultural heritage properties of exceptional importance stand out: the historical ensemble of Sopoćani Monastery, which includes Old Ras, Saint George's Pillars and Saint Peter's Church, all protected by UNESCO (Roganović et al. 2020). The particular gastronomic offer of Golija is related to the exceptional nutritional value of the area's agricultural products (Arsić et al. 2010).

\section{Methodology}

The research examines the motivation of people visiting Golija-Studenica BR and their degree of satisfaction with particular elements of its tourism offer. The aim of this paper is to determine the impacts of gender on visitor motivation and satisfaction with Golija-Studenica BR's tourism offer.-

The primary data were collected using a survey questionnaire. Motivation and satisfaction scales are based on studies done by Kozak (2002), Lee et al. (2004) and Ma et al. (2018), and on the analysis of Golija-Studenica BR's tourism offer. The first part of the questionnaire covers visitors' sociodemographic characteristics: gender, age and level of education. The second part consists of 12 closed questions concerning the basic motives for visiting Golija-Studenica BR. The answers to these used a 5-point Likert scale (1 - I completely disagree, 5 - I completely agree). The third part of the questionnaire refers to the satisfaction with various elements of Golija-Studenica BR's tourism offer.

In August 2019, the authors visited Golija-Studenica BR. This was an opportunity to distribute the questionnaires to the receptionists and owners of private accommodation facilities, who later asked their guests to fill them in after checking out. A total of 860 questionnaires were distributed, of which 700 were completed by guests staying in hotels (280), rural households (160), boarding houses (60), villas (50), apartments (50), and mountain lodges (100). The response rate was $81.4 \%$. After reviewing all question- 


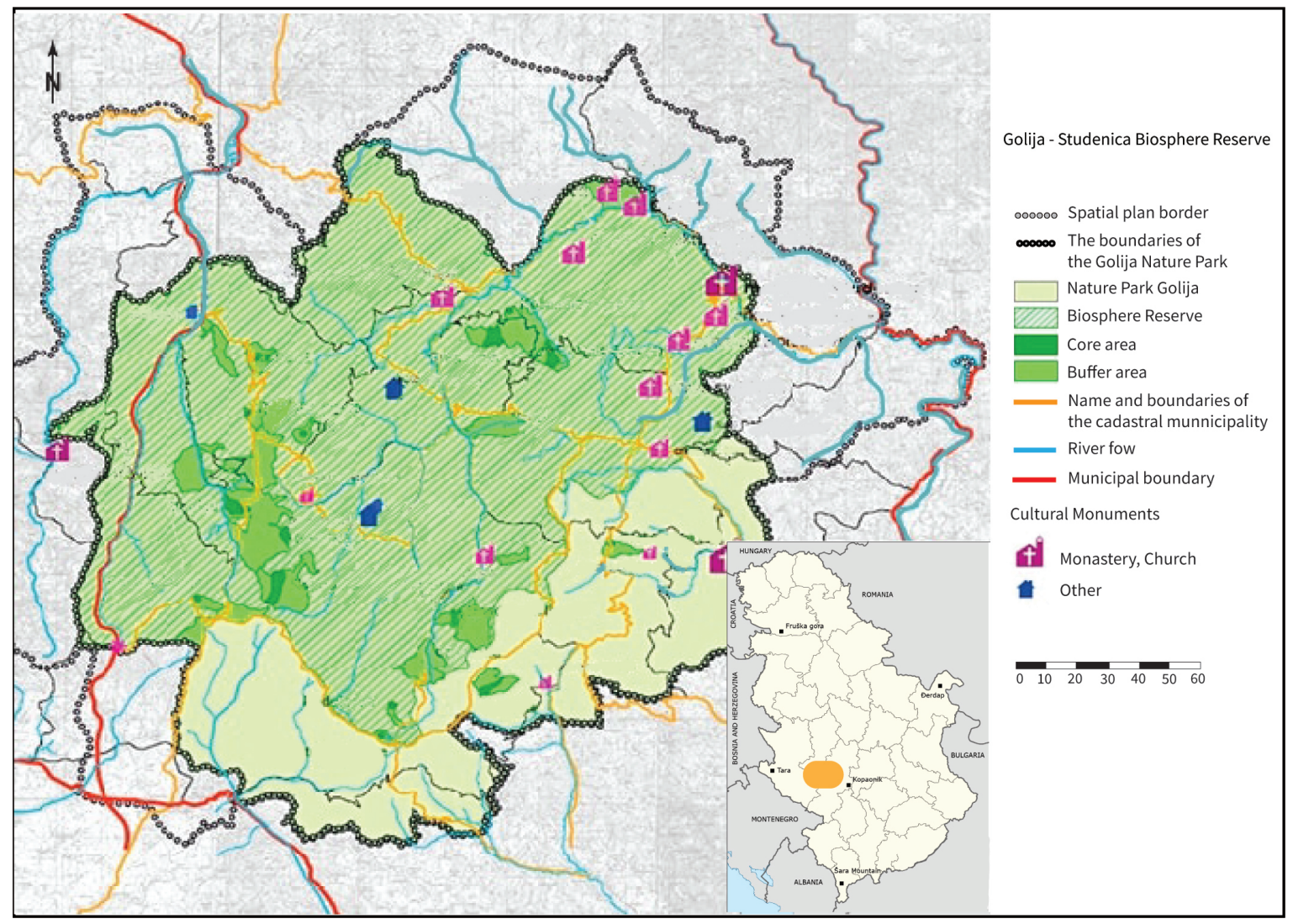

Figure 1 - Golija-Studenica Biosphere Reserve. Source: MediaSfera 2020, modified by the authors

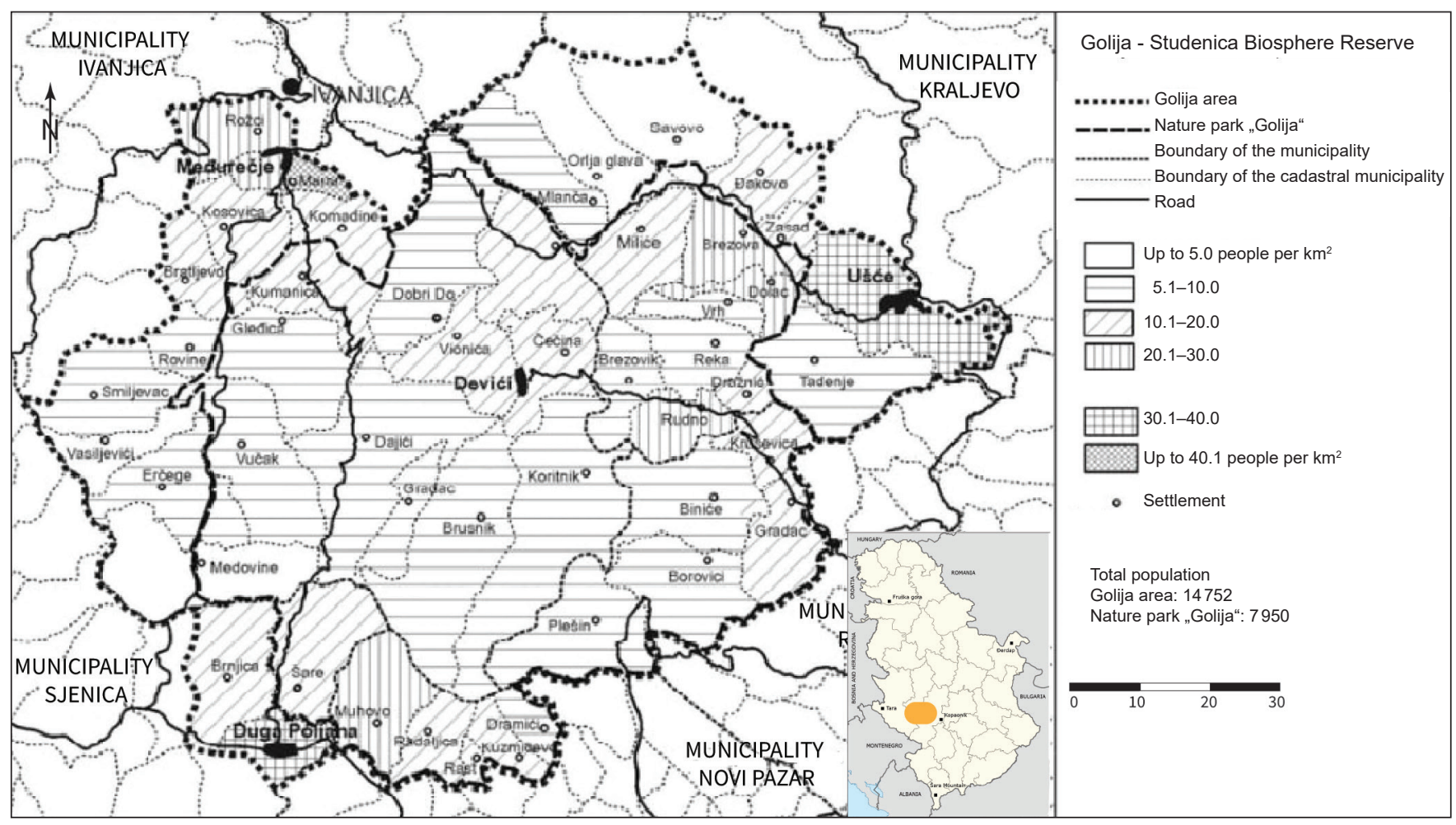

Figure 2 - Golija-population and settlements. Source: Vojkovic \& Stojanovic 2006, modified by the authors

naires, it was found that 642 were adequately completed, giving a final response rate of $74.6 \%$.

The data collected in this research were sorted, tabulated and analysed using the SPSS, v.21. Factor analysis was used to reveal dimensions of visitor motivation and satisfaction. The internal consistency of the sample was verified using Cronbach's alpha coefficient. To check the relationship between motivation 
and satisfaction, regression analysis was used. Using the regression analysis, the relationships between the independent and dependent variables were described and quantified according to gender.

\section{Results}

The survey included 642 visitors, of whom 50\% were women and 50\% were men. Most visitors belong to the age groups $21-40(41.28 \%)$ and $41-60$ $(40.80 \%)$. In terms of education, the single largest group ( $45.17 \%$ of the total number surveyed) left education when they completed high school. The sociodemographic characteristics of respondents are shown in Table 1.

Table 1 - Sociodemographic characteristics of respondents.

\begin{tabular}{|l|l|r|r|}
\cline { 3 - 4 } \multicolumn{2}{c|}{} & Frequency & (\%) \\
\hline \multirow{4}{*}{ Gender } & Male & 321 & 50.0 \\
\cline { 2 - 4 } & Female & 321 & 50.0 \\
\hline \multirow{5}{*}{ Education } & $<20$ & 15 & 2.34 \\
\cline { 2 - 4 } & $21-40$ & 265 & 41.28 \\
\cline { 2 - 4 } & $41-60$ & 262 & 40.80 \\
\cline { 2 - 4 } & $61-80$ & 100 & 15.58 \\
\cline { 2 - 4 } & High school graduate & 290 & 45.17 \\
\cline { 2 - 4 } & Bachelor's degree & 210 & 32.71 \\
\cline { 2 - 4 } & Master's degree & 131 & 20.40 \\
\cline { 2 - 4 } & Doctorate & 11 & 1.71 \\
\hline
\end{tabular}

The main motives for visiting Golija-Studenica $\mathrm{BR}$, rated by the respondents on a 5-point Likert scale, were subjected to factor analysis. First, the appropriateness of using factor analysis was checked. To simplify the loadings of items, Varimax rotation was used. A considerable number of variables correlated at the 0.30 level or above. The data was considered suitable for factor analysis because the Kaiser-Meyer-Oklin value was 0.796 , and because the statistical significance according to Bartlett's Test of Sphericity was confirmed $(p=.000)$. The Scree plot identified a break after the second factor. Factor 1 (Passive motives) and Factor 2 (Active motives) were therefore included in further analysis. All items had factor loadings of more than 0.5 . Factor 1 explained $40.34 \%$ of the variance, and Factor $227.09 \%$. This means that $67.43 \%$ of the total variance was explained by these two factors. Cronbach's alpha, i.e. a reliability coefficient of 0.801 for Passive motives and of 0.732 for Active motives, confirmed that reliability was achieved. The motives rated over 4.50 were $\mathrm{M}_{7}$ : Active vacation in nature (Skiing, Hiking, Biking, Mountain climbing, etc.); $\mathrm{M}_{8}$ : Picking medicinal herbs, forest fruits or mushrooms; $\mathrm{M}_{3}$ : Educational eco-tours; $\mathrm{M}_{4}$ : Enjoying viewpoints and landscapes; $\mathrm{M}_{11}$ : Hunting; $\mathrm{M}_{12}$ : Fishing. Overall, the mean score of the Active motives was 4.43, while the Passive motives had a slightly lower rating, of 4.28 (Table 2).

Factor analysis was also used to reveal dimensions of visitor satisfaction with elements of Golija-Studenica BR's tourism offer. According to a Kaiser-MeyerOklin value of 0.796 , and the statistical significance of Bartlett's Test of Sphericity $(p=.000)$, data was suitable for factor analysis. The Varimax rotation revealed the presence of a simple structure of factor loadings. Four factors explaining $67.43 \%$ of variance were derived: Facilities and services (21.76\% of variance), Preservation $(17.67 \%$ of variance), Organized activities $(10.74 \%$ of variance), and Hospitality and approachability (8.54\% of variance). Factor loadings for all items were found to be above 0.5. Cronbach's alpha ranged from 0.697 (Hospitality and approachability) to 0.865 (Facilities and services). Visitors gave the highest scores (i. e. ratings over 4.50) to the following elements of the tourism offer: $\mathrm{S}_{6}:$ Wealth and preservation of natural beauty, flora, and fauna; $\mathrm{S}_{2}$ : Quality and diversity of gastronomic offer, $\mathrm{S}_{3}$ : Quality and diversity of outdoor sports and recreational offer, $\mathrm{S}_{9}: \mathrm{Or}$ ganization of excursions to introduce the traditions and customs of local communities. According to mean scores of factors, Organized activities were rated highest $(M=4.46)$, while Hospitality and approachability were rated lowest $(M=3.84)$ (Table 3).

Table 2 - Visitor motivation for visiting Golija-Studenica BR. Factor analysis results and mean values.

\begin{tabular}{|c|c|c|c|c|c|}
\hline Factor & $\begin{array}{l}\text { Factor } \\
\text { loading }\end{array}$ & $\begin{array}{l}\text { Eigen } \\
\text { value }\end{array}$ & $\begin{array}{l}\text { Explained } \\
\text { variance }\end{array}$ & $\begin{array}{l}\text { Cronbach's } \\
\text { Alpha }\end{array}$ & Mean \\
\hline Factor 1: Passive motives & & 4.039 & $40.34 \%$ & 0.801 & 4.28 \\
\hline $\mathbf{M}_{1}$ - Passive vacation in nature & 0.921 & & & & 4.16 \\
\hline$M_{2}$ - Introduction to the local way of life (culture, traditions, gastronomy) & 0.811 & & & & 4.18 \\
\hline$M_{3}-$ Educational eco-tours & 0.789 & & & & 4.61 \\
\hline $\mathbf{M}_{4}-$ Enjoying viewpoints and landscapes & 0.766 & & & & 4.54 \\
\hline$M_{5}-$ Wildlife watching & 0.732 & & & & 4.21 \\
\hline$M_{6}-$ Cultural-historical heritage & 0.654 & & & & 3.97 \\
\hline Factor 2: Active motives & & 3.251 & $27.09 \%$ & 0.732 & 4.43 \\
\hline $\mathbf{M}_{\mathbf{7}}-$ Active vacation in nature (Skiing, Hiking, Biking, Mountain climbing, etc.) & 0.841 & & & & 4.88 \\
\hline $\mathbf{M}_{8}-$ Picking medicinal herbs, forest fruits or mushrooms & 0.715 & & & & 4.75 \\
\hline $\mathbf{M}_{9}-$ Camping \& Picnics & 0.651 & & & & 3.92 \\
\hline$M_{10}$ - Environmental events and workshops & 0.636 & & & & 4.00 \\
\hline$M_{11}-$ Hunting & 0.513 & & & & 4.51 \\
\hline $\mathbf{M}_{12}$ - Fishing & 0.501 & & & & 4.54 \\
\hline Total variance explained & & & $67.43 \%$ & & \\
\hline
\end{tabular}


Table 3 - Satisfaction with the elements of Golija-Studenica BR's tourism offer: factor analysis results and mean values.

\begin{tabular}{|c|c|c|c|c|c|}
\hline Factor & \begin{tabular}{|l|} 
Factor \\
loading
\end{tabular} & \begin{tabular}{|l|l|} 
Eigen \\
value
\end{tabular} & \begin{tabular}{|l|} 
Explained \\
variance
\end{tabular} & $\begin{array}{l}\text { Cronbach's } \\
\text { Alpha }\end{array}$ & Mean \\
\hline Factor 1: Facilities and services & & 2.61 & $21.76 \%$ & 0.865 & 4.24 \\
\hline $\mathbf{S}_{1}$ - Quality and diversity of accommodation facilities & 0.796 & & & & 3.98 \\
\hline$S_{2}-$ Quality and diversity of gastronomic offer & 0.751 & & & & 4.77 \\
\hline$S_{3}$ - Quality and diversity of outdoor sports and recreational offer & 0.736 & & & & 4.62 \\
\hline $\mathbf{S}_{4}-$ Picnic and camping sites & 0.531 & & & & 4.13 \\
\hline $\mathbf{S}_{5}-$ Tourist info. centres and info. points & 0.519 & & & & 3.70 \\
\hline Factor 2: Preservation & & 2.12 & $17.67 \%$ & 0.803 & 4.34 \\
\hline$S_{6}-$ Wealth and preservation of natural beauty, flora and fauna & 0.863 & & & & 4.86 \\
\hline $\mathbf{S}_{7}-$ Wealth and preservation of cultural and historical heritage & 0.820 & & & & 4.03 \\
\hline $\mathbf{S}_{8}$ - Preservation of rural area and traditional rural architecture & 0.744 & & & & 4.15 \\
\hline Factor 3: Organized activities & & 1.29 & $10.74 \%$ & 0.702 & 4.46 \\
\hline $\begin{array}{l}\mathbf{S}_{9}-\text { Organized excursions with the purpose of introducing the traditions and customs } \\
\text { of local communities }\end{array}$ & 0.622 & & & & 4.50 \\
\hline $\mathbf{S}_{10}-$ Quality and organization of educational content & 0.609 & & & & 4.43 \\
\hline Factor 4: Hospitality and approachability & & 1.03 & $8.54 \%$ & 0.697 & 3.84 \\
\hline $\mathbf{S}_{11}-$ Hospitality and approachability of employees and local population & 0.771 & & & & 3.89 \\
\hline $\mathbf{S}_{12}-$ Road access & 0.589 & & & & 3.80 \\
\hline Total variance explained & & & $58.71 \%$ & & \\
\hline
\end{tabular}

Based on the factor analysis, several regression analysis models were set up in order to check whether the composite motivation factors for visiting GolijaStudenica BR (passive and active motives) were important in determining each composite factor of satisfaction with elements of the destination's tourist offer (satisfaction with facilities and services, preservation, organized activities, and hospitality and approachability). These composite factors of satisfaction were taken as constant variables, and therefore four models were defined in order to run the regression analysis. The results of the regression analysis showed that $25.9 \%$ of the variation pertaining to satisfaction with facilities and services was explained by the variables included in Model 1. The passive motives were considered the most important indicators of visitor satisfaction with facilities and services in Golija-Studenica BR: their statistical significance was $0.003(p<.10)$. Passive motives also had a significant impact on visi- tor satisfaction with facilities and services $(\beta=.361)$. A total of $32.3 \%$ of the variation concerning satisfaction with preservation was explained by the variables included in Model 2. The results indicated that, once again, passive motives were important indicators, in this case for visitor satisfaction with preservation in Golija-Studenica BR $(p=.000)$, and that they had a significant impact on this type of satisfaction $(\beta=.329)$. In terms of satisfaction with organized activities, the variables included in Model 3 explained $28.6 \%$ of the variation. The statistical significance of active motives in this model was .001, meaning that such motives are important indicators in determining visitor satisfaction with organized activities in Golija-Studenica BR. With a beta coefficient score of .377 , active motives were shown to significantly impact visitor satisfaction with organized activities. The variables included in Model 4 explained $31.6 \%$ of the variation concerning satisfaction with hospitality and approachability. The

Table 4 - Results of several regression analysis.

\begin{tabular}{|c|c|c|c|}
\hline & Std. Beta Coefficient & t-value & Sig. level \\
\hline \multicolumn{4}{|l|}{ Model $1\left(\right.$ Note: $R^{2}=.259 ; F$ change $\left.=8.383 ; p=.000\right)$} \\
\hline Satisfaction with facilities and services (constant) & & 3.321 & 0.034 \\
\hline Passive motives & 0.361 & 5.601 & 0.003 \\
\hline Active motives & -0.084 & -1.425 & 0.211 \\
\hline \multicolumn{4}{|l|}{ Model 2 (Note: $R^{2}=.323 ; F$ change $\left.=9.362 ; p=.000\right)$} \\
\hline Satisfaction with preservation (constant) & & 2.152 & 0.021 \\
\hline Passive motives & 0.329 & 5.230 & 0.000 \\
\hline Active motives & 0.071 & 1.728 & 0.459 \\
\hline \multicolumn{4}{|l|}{ Model $3\left(\right.$ Note: $R^{2}=.286 ; F$ change $\left.=7.452 ; p=.000\right)$} \\
\hline Satisfaction with organized activities (constant) & & 2.135 & 0.022 \\
\hline Passive motives & -0.012 & -0.030 & 0.972 \\
\hline Active motives & 0.377 & 5.989 & 0.001 \\
\hline \multicolumn{4}{|l|}{ Model $4\left(\right.$ Note: $R^{2}=.316 ; F$ change $\left.=9.614 ; p=.000\right)$} \\
\hline Satisfaction with hospitality and approachability (constant) & & 3.101 & 0.041 \\
\hline Passive motives & 0.015 & 0.820 & 0.263 \\
\hline Active motives & 0.032 & 0.850 & 0.597 \\
\hline
\end{tabular}


Table 5 - Standardized coefficient derived from multiple regressions according to gender, for each satisfaction factor. ${ }^{*} p(t)<.05$

\begin{tabular}{|c|c|c|c|c|c|c|c|c|}
\hline & \multicolumn{4}{|l|}{ Male } & \multicolumn{4}{|l|}{ Female } \\
\hline & \multicolumn{8}{|c|}{ Satisfaction with } \\
\hline & $\begin{array}{l}\text { facilities and } \\
\text { services }\end{array}$ & preservation & $\begin{array}{l}\text { organized } \\
\text { activities }\end{array}$ & $\begin{array}{l}\text { hospitality and } \\
\text { approach- } \\
\text { ability }\end{array}$ & $\begin{array}{l}\text { facilities and } \\
\text { services }\end{array}$ & preservation & $\begin{array}{l}\text { organized } \\
\text { activities }\end{array}$ & $\begin{array}{l}\text { hospitality and } \\
\text { approach- } \\
\text { ability }\end{array}$ \\
\hline $\begin{array}{l}\text { Passive } \\
\text { motives }\end{array}$ & $0.42^{\circ}$ & 0.02 & 0.15 & -0.19 & $0.74^{*}$ & $0.36^{*}$ & 0.03 & $0.33^{\circ}$ \\
\hline \multirow{2}{*}{$\begin{array}{l}\text { Active } \\
\text { motives }\end{array}$} & 0.17 & 0.09 & $0.61^{\circ}$ & $0.32^{*}$ & -0.02 & $0.59^{\circ}$ & $0.87^{\circ}$ & -0.14 \\
\hline & $\begin{array}{l}R^{2}=.301 ; \\
F \text { change }= \\
8.542 ; \\
p=.000\end{array}$ & $\begin{array}{l}R^{2}=.319 ; \\
F \text { change }= \\
9.298 ; \\
p=.000\end{array}$ & $\begin{array}{l}R^{2}=.279 ; \\
F \text { change }= \\
7.359 ; \\
p=.000\end{array}$ & $\begin{array}{l}R^{2}=.315 ; \\
F \text { change }= \\
9.620 ; \\
p=.000\end{array}$ & $\begin{array}{l}R^{2}=.248 \\
F \text { change }= \\
8.102 ; \\
p=.000\end{array}$ & $\begin{array}{l}R^{2}=.341 ; \\
F \text { change }= \\
9.412 ; \\
p=.000\end{array}$ & $\begin{array}{l}R^{2}=.294 ; \\
F \text { change }= \\
7.653 ; \\
p=.000\end{array}$ & $\begin{array}{l}R^{2}=.318 ; \\
F \text { change }= \\
9.706 ; \\
p=.000\end{array}$ \\
\hline
\end{tabular}

results indicated that neither passive $(p=.263)$ nor active motives $(p=.597)$ were important indicators in determining visitors' satisfaction with hospitality and approachability.

The additional gender-specific regression analysis aimed to investigate whether passive or active motives were important indicators of gender-based differences relating to the four factors of satisfaction. Men were found to identify passive motives as important indicators of satisfaction with facilities and services, while women considered passive motives to be significant drivers of satisfaction with preservation, hospitality and approachability, as well as satisfaction with facilities and services. Active motives were shown to have an impact on satisfaction with organized activities for both groups, men and women alike. Active motives were also identified as good predictors of satisfaction with hospitality and approachability in men, and of satisfaction with preservation in women (Table 5).

\section{Discussion}

According to studies, the dominant motives for visiting nature reserves are the excitement of seeing animals up close, taking part in different activities, having an enjoyable experience, and feeling a sense of wonder or awe. The most common visitor activities in biosphere reserves include enjoying the scenery, trekking and hiking (Ballantyne et al. 2011; Panin \& Mbrica 2014; Hakim \& Soemarno 2017; Carvache-Franco et al. 2020; Sánchez-Martín et al. 2020). The results of this study indicate that the main motives for visiting Golija-Studenica BR are primarily active ones, such as M7: an active vacation in nature (Skiing, Hiking, Biking, Mountain climbing, etc.); M8: Picking medicinal herbs, forest fruits, or mushrooms; M11: Hunting; M12: Fishing. When it comes to passive motives, the most dominant are M3: Educational eco-tours and M4: Enjoying viewpoints and landscapes. These findings are similar to those of papers by other authors, where the dominant motives are linked to enjoyment, learning and discovery (Vistad et al. 2020; Ballantyne et al. 2011).

The study carried out by Meng et al. (2008) points out that motivation factors do not have have any sta- tistically highly significant impact on visitor satisfaction with a tourist destination. Our research, on the other hand, indicates that passive motives are significantly important indicators of visitor satisfaction with preservation, as well as with the facilities and services offered in Golija-Studenica BR, while active motives are significantly important indicators in determining satisfaction with organized activities. Where gender is concerned, some earlier studies suggest that female tourists are motivated to stay in nature for the purposes of learning, enjoyment of well-preserved landscapes and passive enjoyment (Li et al. 2005; Saayman \& Van der Merwe 2008; Kruger \& Saayman 2010). McGehee et al. (2007) note that the importance of gender in tourism should not be overlooked. Beerli and Martin's (2004) research shows that there are gender differences in the satisfaction of people who are visiting a destination for the first time. Also, according to their study, women rate the natural and cultural values of tourism destinations, as well as their infrastructure, more highly than men do. Heung et al. (2001) state that women more than men prefer to use their free time for travelling. Kim et al. (2003) find that women place more importance on the push factor of family togetherness and study, whereas men emphasize pull factors of appreciating natural resources and health and adventure and building friendships; as a pull factor, women perceived key tourist resources at national parks to be more important than did men. The results of our study also indicate that there are indeed gender-based differences when it comes to motivation and satisfaction with the BR's tourism offer: passive motives are better predictors of women's satisfaction with the offer (Satisfaction with facilities and services, Satisfaction with preservation, Satisfaction with hospitality and approachability) than is the case for men (Satisfaction with facilities and services). There are also differences when it comes to active motives: these are good predictors of men's satisfaction with hospitality and approachability, and for women's satisfaction with preservation.

In future, the development of a tourism destination should take visitor satisfaction into account. While Vigolo et al. (2018) point out that gender has no impact on visitor satisfaction, our research points out that there are differences between women and 
men regarding their motivation and satisfaction with Golija-Studenica BR's tourism offer.

\section{Conclusion}

The development of tourism in biosphere reserves can have multidimensional significance for the entire region. Based on the research results and discussion presented in this study, it can be concluded that there are gender differences among people visiting GolijaStudenica BR where their motivation and satisfaction with the tourism offer are concerned. Passive motives are more likely to influence the satisfaction of female visitors to the $\mathrm{BR}$, while active motives are predictors of their satisfaction with preservation. On the other hand, active motives are important indicators of satisfaction with hospitality and approachability for male visitors. For both female and male visitors, passive motives are predictors of satisfaction with facilities and services, and active ones are predictors of satisfaction with organized activities. The results also indicate that passive motives are important indicators for visitor satisfaction with preservation, facilities and services, while active motives are significantly important indicators in determining satisfaction with organized activities.

Studies examining visitor motivation and satisfaction in natural areas are important for the implementation of preservation strategies, while information about visitors' experience in such areas may support their future protection. The identification of motives that can determine visitor satisfaction independently of the visit motivation is very useful in terms of destination marketing planning. Bearing in mind that visitors are heterogeneous, their demographic profiles should be taken into consideration in the development of tourism products and promotional programmes. More diverse nature-based tourism services should provide financial incentives to local residents to encourage tourism and support the conservation goals of the biosphere reserve (Hearne \& Santos 2005).

The results of the present research have both scientific and practical value. This study aims to explore the actual and potential contributions of biosphere reserves to tourism development, while the results can be used for comparison with biosphere reserves around the world. There are no earlier studies investigating visitor motivation and satisfaction with regard to BRs in Serbia. Furthermore, this study makes a scientific contribution to the international knowledge base about visitors' motives and satisfaction in biosphere reserves. Further scientific implications of this study are evident: to date, there have been no studies that focus on gender differences in visitor motivation and satisfaction regarding biosphere reserves. The practical aspect of this contribution lies in the possibility of using the results to modify Golija-Studenica BR's tourism offer in such a way as to satisfy visitors' needs and demands that are conditioned by various sociodemographic characteristics. The main limita- tions of this study are related to the time period during which the survey was conducted. Future research should be conducted throughout the year, and additionally could focus on day-trippers who come to Golija from nearby tourist centres. The questionnaire should be expanded with questions relating to the satisfaction of day-trippers, accessibility of reserves, quality of infrastructure, and respect for the principles of sustainable development and environmental protection. It should also allow a much more detailed analysis of sociodemographic characteristics of visitors, such as age, marital status and level of education.

As this research relates only to visitors to GolijaStudenica BR, a similar study of motivation and satisfaction with the tourism offer of another biosphere reserve in Serbia, Bačko Podunavlje, is needed. Future research could also analyse the attitudes of the local populations, which could contribute to improving the quality of the tourism offer, and nature preservation and conservation.

\section{References}

Andreu, L., M. Kozak, N. Avci \& N. Cifter 2006. Market segmentation by motivations to travel: British tourists visiting Turkey. Journal of Travel \& Tourism Marketing 19(1): 1-14.

Arsić, S., N. Kljajić \& M. Savić 2010. Possibilities to increase autochthonous dairy production in the $\mathrm{Mu}-$ nicipality of Štrpce, Serbia. Petroleum-Gas University of Ploiesti Bulletin, Economic Sciences Series 62: 37-44.

Baker, D.A. \& J.L. Crompton 2000. Quality, satisfaction and behavioral intentions. Annals of Tourism Research 27: 785-804.

Ballantyne, R., J. Packer \& J. Falk 2011. Visitors' learning for environmental sustainability: Testing short-and long-term impacts of wildlife tourism experiences using structural equation modelling. Tourism Management 32(6): 1243-1252.

Beerli, A. \& J.D. Martín 2004. Tourists' characteristics and the perceived image of tourist destinations: a quantitative analysis-a case study of Lanzarote, Spain. Tourism Management 25(5): 623-636.

Beh, A. \& B.L. Bruyere 2007. Segmentation by visitor motivation in three Kenyan national reserves. Tourism Management 28: 1464-1471.

Biosphärenpark Wienerwald Management 2016. International Network of the UNESCO's Biosphere Reserves. Available at: https://www.bpww.at/en/artikel/ international-network-of-the-unescos-biospherereserves (accessed: 20/09/2021)

Braun, V., C. Diry, H. Mayer, A. Weber \& G. Köck 2020. Conservation, development and logistical support: How are these three functions incorporated in Austrian Biosphere Reserves? eco mont - Journal on Protected Mountain Areas Research and Management 12: 52-57.

Brown, L. \& H. Osman 2017. The female tourist experience in Egypt as an Islamic destination. Annals of Tourism Research 63: 12-22. 
Buckley, R. 2009. Ecotourism: Principles and Practices. Wallingford, UK.

Carvache-Franco, M., W. Carvache-Franco, O. Carvache-Franco, A.B. Hernández-Lara \& C.V. Buele 2020. Segmentation, motivation, and sociodemographic aspects of tourist demand in a coastal marine destination: a case study in Manta (Ecuador). Current Issues in Tourism 23(10): 1234-1247.

Carvache-Franco, M., O. Carvache-Franco, W. Carvache-Franco \& C. Villagómez-Buele 2020. From satisfaction in eco-tourism to loyality in a national park. GeoJournal of Tourism and Geosites 28 (1):191-202.

Chen, P. J. \& D.L. Kerstetter 1999. International students' image of rural Pennsylvania as a travel destination. Journal of Travel Research 37(3): 256-266.

Diaz-Christiansen, S., T. López-Guzmán \& J.C. Pérez-Gálvez 2016. Motivations and valued attributes of ecotourism in a natural protected area: Santay Island (Ecuador). Mediterranean Journal of Social Sciences 7(3): 240-249.

Dingarac, S. \& N. Pesic 2011. Gradac monastery and nature park Golija, Serbia. In: Mallarach, J-M. (ed.), Spiritual Values of Protected Areas of Europe. BfN Skripten 322, Federal Agency for Nature Conservation: 97-103 Bonn.

Figueroa-Domecq, C., A. Pritchard, M. SegoviaPerez, N. Morgan \& T. Villace-Moliero 2015. Tourism gender research: a critical accounting. Annals of Tourism Research 52: 87-103.

Fung, C.K. \& C.Y. Jim 2015. Segmentation by motivation of Hong Kong Global Geopark visitors in relation to sustainable nature-based tourism. International Journal of Sustainable Development \& World Ecology 22(1): 76-88.

Hakim, L. \& M. Soemarno 2017. Biodiversity conservation, community development and geotourism development in bromo-tengger-semeru-arjuno biosphere reserve. Geojournal of Tourism and Geosites 2(20): 220-230.

Hearne, R.R. \& C.A. Santos 2005. Tourists 'and locals'preferences toward ecotourism development in the Maya Biosphere Reserve, Guatemala. Environment, Development and Sustainability 7(3): 303-318.

Heung, V.C., H. Qu \& R. Chu 2001. The relationship between vacation factors and socio-demographic and travelling characteristics: The case of Japanese leisure travellers. Tourism Management 22(3): 259-269.

Institute for Nature Conservation of Serbia, 2020. Biosphere Reserves. Available at https://www. zzps.rs/wp/rezervoati-biosfere/?lang=en (accessed: 20/09/2020)

Ivanovski, A. \& A. Popović 2018. Basic characteristics of sports tourism. Journal of the Anthropological Society of Serbia 53: 39-46.

Jang, S.S. \& R. Feng 2007. Temporal destination revisit intention: The effects of novelty seeking and satisfaction. Tourism Management 28(2): 580-590.

Jönsson, C. \& D. Devonish 2008. Does nationality, gender, and age affect travel motivation? a case of visitors to the Caribbean Island of Barbados. Journal of Travel \& Tourism Marketing 25(3-4): 398-408.

Josimovic, B. \& T. Crncevic 2012. The development of renewable energy capacities in Serbia: Case study of three small hydropower plants in the „Golija“ biosphere reserve with special reference to the landscape heritage. Renewable Energy 48: 537-544.

Kim, S.S., M. Kim, J. Park \& Y. Guo 2008. Cave tourism: Tourists' characteristics, motivations to visit, and the segmentation of their behavior. Asia Pacific Journal of Tourism Research 13(3): 299-318.

Kim, S.S., C.K. Lee \& D.B. Klenosky 2003. The influence of push and pull factors at Korean national parks. Tourism Management 24(2): 169-180.

Köck, G., G. Koch \& C. Diry 2009. The UNESCO Biosphere Reserve „Biosphärenpark Wienerwald” (Vienna Woods) - a long history of conservation. eco.mont - Journal on Protected Mountain Areas Research and Management 1(1): 51-56.

Kozak, M. 2002. Comparative analysis of tourist motivations by nationality and destinations. Tourism Management 23(3): 221-232.

Krejić, Ž., S. Čerović \& S. Milićević 2016. Impact of socio-demographic characteristics on travel expenditures of Hungarian tourists in the village of Skorenovac. Economics of Agriculture 63(2): 601-615.

Krejić, Ž., S. Čerović \& S. Milićević 2017. Historical development of tourism in Serbia. Hotel and Tourism Management 5(1): 55-63.

Kruger, M. \& M. Saayman 2010. Travel motivation of tourists to Kruger and Tsitsikamma National Parks: A comparative study. South African Journal of Wildlife Research 40(1): 93-102.

Kwok, S.Y., A. Jusoh \& Z. Khalifah 2016. The influence of service quality on satisfaction: Does gender really matter? Intangible Capital 12(2): 444-461.

Lakićević, M. \& Z. Sagić 2019. Accommodation capacities and their utilization in the function of tourism development: Case of Ivanjica. Ekonomika 65(3): 77-88.

Lee, C.K., Y.K. Lee \& B.E. Wicks 2004. Segmentation of festival motivation by nationality and satisfaction. Tourism Management 25(1): 61-70.

Lee, Seungwoo, Sangtak Lee \& G. Lee 2014. Ecotourists' motivation and revisit intention: A case study of restored ecological parks in South Korea. Asia Pacific Journal of Tourism Research 19(11): 1327-1344.

Li, W., X. Ge \& C. Liu 2005. Hiking trails and tourism impact assessment in protected area: Jiuzhaigou Biosphere Reserve, China. Environmental Monitoring and Assessment 108(1-3): 279-293.

Ma, A.T.H, A.S.Y. Chow, L.T.O. Cheung, K.M.Y. Lee \& S. Liu 2018. Impacts of tourists' sociodemographic characteristics on the travel motivation and satisfaction: The case of protected areas in South China. Sustainability 10(10): 3388.

Mahika, E.C. 2011. Current trends in tourist motivation. Cactus Tourism Journal 2(2): 15-24. 
McGehee, N.G., K. Kim \& G.R. Jennings 2007. Gender and motivation for agri-tourism entrepreneurship. Tourism Management 28(1): 280-289.

Mehmetoglu, M. \& Ø. Normann, 2013. The link between travel motives and activities in nature-based tourism. Tourism Review 68: 3-13.

Meng, F., Y. Tepanon \& M. Uysal 2008. Measuring tourist satisfaction by attribute and motivation: The case of a nature-based resort. Journal of Vacation Marketing 14(1): 41-56.

Milićević, S., N. Đorđević \& Ž. Krejić 2020. Research on tourists' attitudes on the potential of Goč mountain for the development of eco-tourism. Economics of Agriculture 67(1): 223-238.

MediaSfera 2020. Map of cultural monuments on the territory of Nature Park Golija. Available at: https:// mediasfera.rs/2017/09/27/20170927svetlana-dingarac-zastita-svetih-prirodnih-mesta-u-svetu-i-kod-nas / mapa-spomenika-kulture-na-teritoriji-pp-golija/ (accessed: 20/09/2021)

Mutanga, C.N., S. Vengesayi, O. Chikuta, N. Muboko \& E. Gandiwa 2017. Travel motivation and tourist satisfaction with wildlife tourism experiences in Gonarezhou and Matusadona National Parks, Zimbabwe. Journal of Outdoor Recreation and Tourism 20: 1-18.

Oviedo-García, M.Á., M. Vega-Vázquez, M. Castellanos-Verdugo \& F. Orgaz-Agüera 2019. Tourism in protected areas and the impact of servicescape on tourist satisfaction, key in sustainability. Journal of Destination Marketing \& Management 12: 74-83.

Panin, B. \& A. Mbrica 2014. Potentials of ecotourism as a rural development tool on the base of motivation factors in Serbia. International Scientific Conference. Sustainable Agriculture and Rural Development in Terms of the Republic of Serbia Strategic Goals Realization within the Danube Region, Rural development and (un)limited resources, Belgrade, Serbia, 5-6 June, 2014: 597-613.

Park, D.B. \& Y.S. Yoon 2009. Segmentation by motivation in rural tourism: A Korean case study. Tourism Management 30(1): 99-108.

Pritchard, A. \& N.J. Morgan 2000. Constructing tourism landscapes - Gender, sexuality and space.Tourism Geographies 2(2): 115-139.

Roganović, D., V. Vandić, J. Aleksić, M. Bartula, M. Milinković, L.Nišavić, M. Petrović, M. de Marchi, L. Lietti, V. Veljović \& R. Čolić 2020. Akcioniplan za područje Parka prirode „Golija“ 2018 - 2022. Available at: http:// www.europeanprogres.org/dokumenti/48_304223_ publikacija-golija-akcioni-plan.pdf (accessed: 20/09/2021)

Rittichainuwat, N. 2008. Responding to disaster: Thai and Scandinavian tourists' motivation to visit Phuket, Thailand. Journal of Travel Research 46(4): 422432.

Ruoss, E. 2013. Biosphere reserves as model sites for sustainable development. Protected Areas in Focus: Analysis and Evaluation. Proceedings in the Management of Protected Areas 4: 99-114.
Ryan, M., N., Henley \& G. Soutar 1998. Gender Differences in Tourism Destination: Implications for Tourism Marketers. Available at: https://ro.ecu.edu.au/smatl_ pubs/13 (accessed: 20/09/2021)

Saayman, M. \& P. Van der Merwe 2008. Travel motivations of tourists visiting Kruger National Park. African Protected Area Conservation and Science 50(1): 154-159.

Sánchez-Martín, J.M., J.I. Rengifo-Gallego \& M. Sánchez-Rivero 2020. Protected areas as a center of attraction for visits from world heritage cities: Extremadura (Spain). Land 9(2): 47.

Sandybayev, A., R. Houjeir \& I. Reczey 2018. Exploring trends in tourism motivation, a case of tourists visiting the United Arab Emirates. Noble International Journal of Social Sciences Research 3(1): 1-8.

Schlagenhauf, P., L.H. Chen, M.E. Wilson, D.O. Freedman, D. Tcheng, E. Schwartz, ... \& GeoSentinel Surveillance Network 2010. Sex and gender differences in travel-associated disease. Clinical Infectious Diseases 50(6): 826-832.

Squire, S.J. 1994. Gender and tourist experiences: assessing women's shared meanings for Beatrix Potter. Leisure Studies 13(3): 195-209.

Suki, N.M. 2014. Moderating role of gender in the relationship between hotel service quality dimensions and tourist satisfaction. Journal of Quality Assurance in Hospitality \& Tourism 15(1): 44-62.

Swain, M. 1995. Gender in tourism. Annals of Tourism Research 22(2): 247-266.

Trišić, I. 2019. Opportunities for sustainable tourism development and nature conservation in Special Nature Reserve "Deliblatska peščara". Hotel and Tourism Management 7(1): 83-93.

Tyrväinen, L., H. Silvennoinen \& V. Hallikainen 2017. Effect of the season and forest management on the visual quality of the nature-based tourism environment: a case from Finnish Lapland. Scandinavian Journal of Forest Research 32(4): 349-359.

Um, S. \& J.L. Crompton 1992. The roles of perceived inhibitors and facilitators in pleasure travel destination decisions. Journal of Travel Research 30(3): 18-25.

UNESCO 2020a. Biosphere Reserves. Available at: https://en.unesco.org/biosphere and https:// unesdoc.unesco.org/ark:/48223/pf0000121361 (accessed: 20/09/2021)

UNESCO 2020b. Golija-Studenica. Available at: https://en.unesco.org/biosphere/eu-na/golija-studenica (accessed: 20/09/2021)

Vigolo, V., F. Simeoni, F. Cassia \& M.M. Ugolini 2018. The effects of travel motivation on satisfaction: the case of older tourists. International Journal of Business and Social Science 9(2): 19-30.

Vistad, O.I., H. Øian, D.R. Williams \& P. Stokowski 2020. Long-distance hikers and their inner journeys: On motives and pilgrimage to Nidaros, Norway. Journal of Outdoor Recreation and Tourism 31: 100326.

Vojković, G. \& B. Stojanović 2006. Golija-Razvitak stanovništva i perspektive. Stanovništvo 44(2): 35-64. 
Wang, C., H. Qu \& M.K. Hsu 2016. Toward an integrated model of tourist expectation formation and gender difference. Tourism Management 54: 58-71.

Wu, C.W. 2015. Foreign tourists' intentions in visiting leisure farms. Journal of Travel Research 68: 757-762.

\section{Authors}

\section{Snežana Milićević}

Associate Professor, University of Kragujevac, Faculty of Hotel Management and Tourism in Vrnjačka Banja, Vojvođanska 5A, Vrnjačka Banja 36210, Serbia. E-mail: snezana.milicevic@kg.ac.rs. ORCID ID https://orcid.org/0000-0002-1972-9585

\section{Živana Krejić}

Assistant Professor, Union University „Nikola Tesla”, Faculty of Business Studies and Law, Jurija Gagarina 149a, 11070 Belgrade, Serbia. E-mail: zivana.krejic@fpsp.edu.rs. ORCID ID https://orcid. org/0000-0003-2490-5755

\section{Nataša Đorđević}

Teaching Assistant, University of Kragujevac, Faculty of Hotel Management and Tourism in Vrnjačka Banja, Vojvođanska 5A, 36210 Vrnjačka Banja, Serbia. E-mail: natasa.djordjevic@kg.ac.rs. ORCID ID https://orcid.org/0000-0002-3630-6867 